\title{
Blood and urine levels of heavy metal pollutants in female and male patients with coronary artery disease
}

This article was published in the following Dove Press journal:

Vascular Health and Risk Management

13 May 2014

Number of times this article has been viewed

\author{
Michael Sponder' \\ Monika Fritzer-Szekeres ${ }^{2}$ \\ Rodrig Marculescu ${ }^{2}$ \\ Martina Mittlböck ${ }^{3}$ \\ Maria Uhl ${ }^{4}$ \\ Birgit Köhler-Vallant ${ }^{5}$ \\ Jeanette Strametz-Juranek' \\ 'Department of Cardiology, Medical \\ University of Vienna, Vienna, Austria; \\ ${ }^{2}$ Department of Medical-Chemical \\ Laboratory Analysis, Medical \\ University of Vienna, Vienna, Austria; \\ ${ }^{3}$ Department of Medical Statistics, \\ Informatics and Intelligent Systems, \\ Section for Clinical Biometrics, \\ Medical University of Vienna, Vienna, \\ Austria; ${ }^{4}$ Department of Pollutants \\ and Human, Environment Agency \\ Austria, Vienna, Austria; ${ }^{5}$ Department \\ of Inorganic Analysis, Environment \\ Agency Austria, Vienna, Austria
}

Background: Heavy metal pollutants such as cadmium $(\mathrm{Cd})$, lead $(\mathrm{Pb})$, and mercury $(\mathrm{Hg})$ are rarely the subjects of cardiovascular research although they have been suspected for decades to negatively impact the circulatory system.

Methods: Apart from detailed anamnestic data, urinary levels of $\mathrm{Cd}$ and full blood levels of $\mathrm{Pb}$ and $\mathrm{Hg}$ were measured in 53 female (mean age: 68.04 \pm 7.03 years) and 111 male (mean age: $60.68 \pm 11.43$ years) nonsmoking or never-smoking patients with angiographically verified and precisely quantified coronary artery disease (CAD).

Results: Although Cd was quantifiable in $68.3 \%$ of subjects, only $34.1 \%$ of these patients exceeded the critical $1 \mu \mathrm{g} / \mathrm{L}$ Human Biomonitoring (HBM)-I level. Median Pb $(20 \mu \mathrm{g} / \mathrm{L})$ and $\mathrm{Hg}$ $(0.55 \mu \mathrm{g} / \mathrm{L})$ levels were lower than the HBM-I, as well as reference levels of $\mathrm{Pb}$. Wine consumption was the main source for $\mathrm{Pb}$, fish and wine consumption for $\mathrm{Hg}$, and previous nicotine abuse for $\mathrm{Cd}$. There was no correlation between $\mathrm{Cd}, \mathrm{Pb}$, or $\mathrm{Hg}$ and severity of $\mathrm{CAD}$ although severity correlated positively with atherosclerosis parameters (uric acid, creatinine, triglycerides, blood urea nitrogen, C-reactive protein) and negatively with high density lipoprotein cholesterol.

Conclusion: Cd levels detected in CAD patients were high compared to German and European reference levels but it could not be proven that urine levels of $\mathrm{Cd}$ and blood levels of $\mathrm{Hg}$ or $\mathrm{Pb}$ played a major role in the genesis of CAD, particularly when compared to well-known biomarkers such as blood pressure, glucose, and lipids.

Keywords: cadmium, plumbum, mercury, coronary artery disease, pollutants

\section{Introduction}

According to the European Cardiovascular Disease Statistics $2012^{1}$ cardiovascular disease (CVD) is responsible for $47 \%$ of all deaths in Europe and $40 \%$ of deaths in the European Union. The most common coronary manifestations of atherosclerosis are acute coronary syndromes such as myocardial infarction or sudden cardiac death and stable angina pectoris. Of course the mortality rate for CVD strongly depends on several risk factors but in general, men are more likely to die of CVD at a rate of 2.5-4.5:1. ${ }^{2}$ Independent of sex-specific differences in risk factors, the absolute level of coronary artery disease (CAD) in men is higher than in women, although the dose response of most risk factors is the same in women and men, even after menopause, a fact that has been known for a long time. ${ }^{3,4}$ Traditional risk factors causing or promoting CAD are nicotine abuse, diabetes mellitus, arterial hypertension, dyslipidemia, physical inactivity, and overweight/obesity. ${ }^{5}$ However, heavy metal pollutants such as cadmium $(\mathrm{Cd})$, lead $(\mathrm{Pb})$, and mercury $(\mathrm{Hg})$ may also contribute to the genesis of coronary atherosclerosis but they are far less commonly subjected to cardiovascular research
Correspondence: Michael Sponder Medical University of Vienna, Department of Cardiology, Währinger Gürtel 18-20, 1090 Vienna, Austria

$\mathrm{Tel}+436502619393$

Fax +43404004216

Email michael.sponder@meduniwien.ac.at submit your manuscript | www.dovepress.com Dovepress 
although the first hints for this assumption were found nearly a century ago. ${ }^{6} \mathrm{Cd}$ was associated with an increased risk for suffering hypertension, cardiac arrest, and stroke. ${ }^{7-9}$ Messner et $\mathrm{a}^{10}$ found a significant association between Cd levels in serum and intima media thickness in female individuals aged 18-22 years. Prozialeck ${ }^{11}$ suggested E-cadherin, a $\mathrm{C}^{++}$-binding protein localized at the junctions between vascular endothelial cells, as a target for $\mathrm{Cd}$ toxicity. $\mathrm{Cd}$ is also able to induce the expression of intercellular adhesion molecule 1 , an adhesion molecule playing an important role in inflammation. ${ }^{12}$ Furthermore, Cd was shown to indirectly generate superoxide and hydroxyl radicals. ${ }^{13}$ Similar to $\mathrm{Cd}$, increased $\mathrm{Hg}$ exposure was also suspected to lead to hypertension and cerebral artery occlusion. ${ }^{14-16}$ Wojciechowski and Kowalski, ${ }^{17}$ working on rabbits, showed that inhaling $\mathrm{Hg}$ vapor over 3 months caused electrocardiogram (ECG) abnormalities, thrombotic lesions in small and medium caliber blood vessels, and necrotic foci. Guallar et a ${ }^{18}$ performed a case-controlled study in eight European countries and Israel and found that amounts of $\mathrm{Hg}$ in toenails were $15 \%$ higher in a group of patients with myocardial infarction compared to controls. Again, similar to Cd, Salonen et a ${ }^{19}$ found a correlation between $\mathrm{Hg}$ amounts in hair and intima media thickness in men from eastern Finland. Like $\mathrm{Cd}$ and $\mathrm{Hg}, \mathrm{Pb}$ measured in blood and bone (tibia and patella) was associated with hypertension, probably by affecting the renin-angiotensin system, increasing angiotensin converting enzyme levels ${ }^{20,21}$ or by influencing the beta-adrenergic system as suggested by Tsao et al..$^{22}$ Another explanation may be an impairment of the balance between vasoconstrictive and vasodilatative factors to the benefit of vasoconstriction. ${ }^{23}$ Furthermore, a damaging effect of $\mathrm{Pb}$ on the endothelium may be due to its potential to increase reactive oxygen species. Reactive oxygen species may also be involved in blood pressure increase by increasing $\mathrm{Ca}^{++}$concentration in endothelial cells or by the inactivation of nitrogen oxide. ${ }^{24}$ The results of the mentioned studies indicate that $\mathrm{Cd}, \mathrm{Hg}$, and $\mathrm{Pb}$ may increase cardiovascular risk by promoting atherosclerosis per se or by ameliorating the circumstances for atherosclerotic processes.

The present study measured Cd levels in urine and $\mathrm{Hg}$ and $\mathrm{Pb}$ levels in blood, and correlated them with the severity of CAD with regard to sex and sex-specific aspects, and compared them with other well established cardiovascular risk factors, eg, blood pressure, blood glucose, and lipids.

\section{Materials and methods}

In total, 111 male and 53 female never-smoking or exsmoking (for at least 7 years) patients with angiographically verified CAD of differing severity were recruited at the Department of Cardiology, Medical University of Vienna. The study group consisted of $49.4 \%$ of patients with chronic $\mathrm{CAD}$, defined as at least one coronary ischemic event in the past documented by coronary angiography, and $50.6 \%$ of patients who had never had an ischemic event.

Detailed anamnestic data were collected by means of an interview taking into account exposure to heavy metal sources like housing, nutrition, past smoking behavior, amalgam fillings, and other factors. Alcohol intake was quantified in units ( 1 unit $=0.02 \mathrm{~L}$ of spirits, $0.25 \mathrm{~L}$ of wine, or $0.3 \mathrm{~L}$ of beer). Meat and fish intake were quantified by times/week. Tap water consumption was measured in L/week. Blood pressure was measured at least three times during the in-patient stay. An ECG was taken, routine laboratory parameters were measured, and all patients had to undergo an angiography for diagnostic and/or therapeutic reasons on the grounds of their underlying disease. The coronary arteries were divided into 17 segments (left main, proximal/medial/distal left anterior descending artery, ramus circumflexus, first and second marginal branch, posterolateral branch, first and second diagonal branch, proximal/medial/distal left circumflex artery, proximal/medial/ distal right coronary artery, ramus interventricularis posterior) and stenosis grade for each segment was measured. A simple 3-point grading system (coronary score) was developed considering both frequency and severity of CAD: 0 points for non-stenosed or only calcified segments, 1 point for each stenosis from $30 \%-<50 \%, 2$ points for each stenosis from $50 \%-<70 \%$, and 3 points for each stenosis $>70 \%$. $\mathrm{Hg}$ and $\mathrm{Pb}$ levels were measured in full blood, and $\mathrm{Cd}$ was measured in urine. The outcrop of full blood samples for the determination of $\mathrm{Pb}$ and $\mathrm{Hg}$ was done by $2 \mathrm{~mL}$ ultrapure water and $2 \mathrm{~mL}$ nitric acid (68\% subboiled). The sample aliquot was $0.5 \mathrm{~mL}$ and the backfilling volume was $20 \mathrm{~mL}$. The determination of $\mathrm{Pb}$ and $\mathrm{Cd}$ was performed by inductively coupled plasma mass spectrometry according to the ÖNORM EN ISO 17294-2. The determination of $\mathrm{Hg}$ was done by atomic fluorescence spectroscopy according to the ÖNORM EN 17852. The outcrop of urine samples for the determination of Cd was done by 2 $\mathrm{mL}$ ultrapure water and $2 \mathrm{~mL}$ nitric acid (68\% subboiled). The sample aliquot was $5 \mathrm{~mL}$ and the backfilling volume was 20 $\mathrm{mL}$. The detection/quantification limits were $0.4 / 2 \mu \mathrm{g} / \mathrm{L}$ for $\mathrm{Pb}, 0.067 / 0.13 \mu \mathrm{g} / \mathrm{L}$ for $\mathrm{Hg}$, and $0.12 / 0.40 \mu \mathrm{g} / \mathrm{L}$ for $\mathrm{Cd}$. In case the quantification limit was undercut, the following expected amounts were used: $\mathrm{Cd}, 0.3 \mu \mathrm{g} / \mathrm{L} ; \mathrm{Pb}, 1 \mu \mathrm{g} / \mathrm{L} ; \mathrm{Hg}, 0.1 \mu \mathrm{g} / \mathrm{L}$. $\mathrm{Cd}$ and $\mathrm{Hg}$ Human Biomonitoring (HBM)-I and -II values and the $\mathrm{Pb}$ reference values from the German Environmental Agency ${ }^{25,26}$ were used for comparison. 
HBM values are derived on the basis of toxicological and epidemiological studies and are a tool to quickly assess whether exposure related health effects can be expected. However, they do not reflect the total body burden of heavy metal pollutants. At a concentration level higher than the HBM-I it is suggested that analytic results be verified to identify specific sources of exposure and to reduce the exposure in an adequate way. At levels higher than HBM-II values immediate action to reduce exposure is required. The reference values permit the assessment of exposure of individuals or population groups compared to ubiquitous background exposure. In the case of $\mathrm{Pb}$, the German Commission has suspended the HBM values for $\mathrm{Pb}$ in blood due to the fact that no threshold can be derived for the persisting adverse effects on brain development and also due to the carcinogenicity of $\mathrm{Pb}$ compounds. ${ }^{27,28}$

Statistical analysis was done with SPSS 20.0 (IBM Corporation, Armonk, NY, USA). Continuous and normally distributed data are described by mean \pm standard deviation, group differences are tested by independent sample $t$-test, and correlation is calculated using Pearson's correlation coefficient. Continuous data with skew distribution or outliers are described by median, first and third quartile, and minimum and maximum values. Group differences are tested by Mann-Whitney $U$ test and correlations were calculated using Spearman's correlation. For data with values below the quantification limit a value below quantification limit was imputed (the same value for all observations) and the nonparametric Mann-Whitney $U$ test was used. All tests were performed two-sided and $P \leq 0.05$ were considered significant. The protocol was approved by the Ethical Commission of the Medical University of Vienna and informed consent was obtained from patients.

\section{Results}

Data concerning age, body mass index (BMI), heart rate, blood pressure, and ECG are shown in Table 1. Male patients were significantly younger compared to female patients $(P<0.01)$. There was no significant difference between BMI $(P=0.22)$, systolic blood pressure $(P=0.88)$, heart rate $(P=0.99)$, and ECG data. However, men showed a significantly higher diastolic blood pressure compared to women $(P<0.01)$. Atrial fibrillation was observed in 13 male and three female patients, PQ in patients without atrial fibrillation was $169.07 \pm 28.98 \mathrm{~ms}$ in male and $155.14 \pm 29.22 \mathrm{~ms}$ in female patients $(P<0.01)$. The prevalence of traditional cardiovascular risk factors is shown in Table 2 . The prevalence of hypertension and previous nicotine abuse was higher in
Table I Anthropometric data, blood pressure, and electrocardiogram data

\begin{tabular}{lcccl}
\hline & Female & Male & Total & P-value \\
\hline Age (years) & $68.04 \pm 7.03$ & $60.68 \pm 11.43$ & $63.05 \pm 10.96$ & $<0.01$ \\
BMI $\left(\mathrm{kg} / \mathrm{m}^{2}\right)$ & $27.28 \pm 5.35$ & $28.40 \pm 5.50$ & $28.04 \pm 5.46$ & 0.22 \\
SBP $(\mathrm{mmHg})$ & $131.26 \pm 16.08$ & $130.86 \pm 15.36$ & $130.99 \pm 15.55$ & 0.88 \\
DBP $(\mathrm{mmHg})$ & $72.15 \pm 8.28$ & $78.41 \pm 11.35$ & $76.39 \pm 10.84$ & $<0.01$ \\
Heart rate & $70.57 \pm 14.01$ & $70.53 \pm 12.85$ & $70.54 \pm 13.19$ & 0.99 \\
(bpm) & & & & \\
PQ (ms) & $155.14 \pm 29.22$ & $169.07 \pm 28.96$ & $164.36 \pm 29.70$ & $<0.01$ \\
QTc (ms) & $453.08 \pm 41.57$ & $440.33 \pm 43.22$ & $444.45 \pm 42.98$ & 0.08 \\
QRS (ms) & $104.74 \pm 28.59$ & $106.01 \pm 44.62$ & $105.60 \pm 40.06$ & 0.85 \\
\hline
\end{tabular}

Notes: Anthropometric data, systolic and diastolic blood pressure, heart rate, and electrocardiogram data of the coronary artery disease patients. Data is presented as mean \pm standard deviation. $P$-values show the sex-specific statistical difference.

Abbreviations: BMI, body mass index; bpm, beats per minute; DBP, diastolic blood pressure; SBP, systolic blood pressure.

male patients whereas female patients had a higher prevalence of diabetes mellitus and physical inactivity, defined as less than 3 hours of walking per week.

Parameters of special interest from routine laboratory analyses are shown in Table 3. Severity of CAD is described in detail in the Materials and methods. Female patients had a mean coronary score of $6.43 \pm 5.87$ points with a maximum of 24 points. Male patients had a mean coronary score of $8.46 \pm 5.29$ with a maximum of 29 points.

The levels of $\mathrm{Cd}, \mathrm{Pb}$, and $\mathrm{Hg}$ among the CAD patients were compared to levels within the German population as well as with HBM-I/II and reference levels. ${ }^{25,26}$ Mean $\mathrm{Cd}, \mathrm{Pb}$, and $\mathrm{Hg}$ levels in the German population were $0.335 \mu \mathrm{g} / \mathrm{L}$, $35.6 \mu \mathrm{g} / \mathrm{L}$, and $0.86 \mu \mathrm{g} / \mathrm{L}$, respectively. The HBM-I level for $\mathrm{Cd}$ is $1 \mu \mathrm{g} / \mathrm{L}$ and $5 \mu \mathrm{g} / \mathrm{L}$ for $\mathrm{Hg}$. The HBM-II levels are $4 \mu \mathrm{g} / \mathrm{L}$ and $15 \mu \mathrm{g} / \mathrm{L}$ for $\mathrm{Cd}$ and $\mathrm{Hg}$, respectively. There are no HBM levels for $\mathrm{Pb}$. Reference levels are $0.8 \mu \mathrm{g} / \mathrm{L}$ for $\mathrm{Cd}, 2.0 \mu \mathrm{g} / \mathrm{L}$ for $\mathrm{Hg}$, and 70 and $90 \mu \mathrm{g} / \mathrm{L}$ for $\mathrm{Pb}$ in women and men, respectively. The heavy metal levels in the CAD patients are

Table 2 Prevalence of traditional risk factors

\begin{tabular}{lllll}
\hline & Female & Male & Total & P-value \\
\hline Hypertension & $94.3(50)$ & $99.3(98)$ & $90.2(148)$ & 0.22 \\
Pos Fam history & $54.7(29)$ & $55.0(61)$ & $54.9(90)$ & 0.98 \\
Diabetes mellitus & $37.8(20)$ & $22.5(25)$ & $45.0(17)$ & 0.04 \\
Diabetes (no insulin) & $20.8(11)$ & $12.6(14)$ & $15.2(25)$ & \\
Diabetes (insulin) & $17.0(9)$ & $9.9(11)$ & $12.2(20)$ & \\
Hyperlipidemia & $88.7(47)$ & $89.2(99)$ & $89.0(146)$ & 0.92 \\
Previous Ml/stroke & $41.5(22)$ & $40.5(35)$ & $40.9(67)$ & 0.97 \\
Ex-smoking & $39.6(21)$ & $65.8(73)$ & $57.3(94)$ & $<0.01$ \\
Physical inactivity & $30.2(16)$ & $27.9(31)$ & $28.7(47)$ & 0.77 \\
\hline
\end{tabular}

Notes: Prevalence in percent $(n)$ of traditional cardiovascular risk factors for female and male coronary artery disease patients. Physical inactivity was defined as $<3$ hours of walking per week. $P$-values show the sex-specific statistical difference.

Abbreviations: Pos Fam, positive family; MI, myocardial infarction. 
Table 3 Important routine laboratory parameters

\begin{tabular}{|c|c|c|c|c|}
\hline & Female & Male & Total & $P$-value \\
\hline Uric acid $(\mathrm{mg} / \mathrm{dL})$ & $5.85 \pm 1.89$ & $6.64 \pm 2.03$ & $6.39 \pm 2.01$ & 0.02 \\
\hline Triglycerides (mg/dL) & |3| (97-169) & $130(94-183)$ & $130(95-176)$ & 0.60 \\
\hline Cholesterol (mg/dL) & $19.222 \pm 48.37$ & $168.45 \pm 48.63$ & $175.98 \pm 49.66$ & $<0.01$ \\
\hline $\mathrm{HDL}(\mathrm{mg} / \mathrm{dL})$ & $54.83 \pm 15.58$ & $41.36 \pm 10.21$ & $45.92 \pm|3.8|$ & $<0.01$ \\
\hline LDL (mg/dL) & 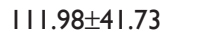 & $100.91 \pm 38.14$ & $104.65 \pm 39.59$ & 0.12 \\
\hline LDL/HDL (mg/dL) & $2.14 \pm 0.88$ & $2.56 \pm 1.09$ & $2.42 \pm 1.04$ & 0.02 \\
\hline $\mathrm{HbA}_{\mathrm{lc}}(\mathrm{rel} \%)$ & $6.1(5.7-7.0)$ & $5.9(5.4-6.4)$ & $6.0(5.5-6.9)$ & 0.10 \\
\hline CRP (mg/dL) & $0.50(0.17-1.60)$ & $0.62(0.22-2.84)$ & $0.59(0.20-2.42)$ & 0.36 \\
\hline
\end{tabular}

Notes: Extract of routine laboratory parameters of special interest. Data are presented as mean \pm standard deviation or median (first to third quartile). $P$-values show the sex-specific statistical difference.

Abbreviations: CRP, C-reactive protein; HDL, high density lipoprotein; $\mathrm{HbA}_{1 \mathrm{c}}$, glycated hemoglobin; LDL, low density lipoprotein.

shown in Table 4. Cd was quantifiable in $68.3 \%$ of patients, $\mathrm{Pb}$ in $100 \%$ of patients, and $\mathrm{Hg}$ in $83.5 \%$ of patients, and the remaining patients were below the quantification limit. Concerning $\mathrm{Cd}$, female patients had higher levels compared to men but men showed higher levels of $\mathrm{Pb}$ and $\mathrm{Hg}$ for which the difference was significant $(P=0.02)$. The $P$-values (and correlation coefficients) for the correlations of the coronary score with $\mathrm{Cd}, \mathrm{Pb}$, and $\mathrm{Hg}$ in female patients was 0.64 (0.07), $0.06(-0.26)$, and $0.51(0.09)$; for male patients it was 0.65 $(-0.05), 0.79(0.03)$, and $0.06(-0.18)$, respectively. Analyzing the whole population, the $P$-values were $0.82(-0.02), 0.50$ $(-0.05)$, and $0.60(-0.04)$ for $\mathrm{Cd}, \mathrm{Pb}$, and $\mathrm{Hg}$, respectively. After splitting the population into patients with chronic CAD (stents, bypasses) and patients who suffered their first event, again there was no significant correlation observable for $\mathrm{Cd}$,

Table 4 Heavy metals in coronary artery disease patients

\begin{tabular}{|c|c|c|c|c|}
\hline & Female & Male & $P$-value & Total \\
\hline \multicolumn{5}{|l|}{ Cd } \\
\hline n (\%) & 67.9 & 68.5 & & 68.3 \\
\hline $\begin{array}{l}\text { Median (first/ } \\
\text { third quartile) }\end{array}$ & $\begin{array}{l}0.72 \\
(<0.40 / 1.45)\end{array}$ & $\begin{array}{l}0.65 \\
(<0.40 / 1.50)\end{array}$ & 0.84 & $\begin{array}{l}0.67 \\
(0.30 / 1.50)\end{array}$ \\
\hline $\begin{array}{l}\text { Minimum/ } \\
\text { maximum }\end{array}$ & $<0.40 / 16.00$ & $<0.40 / 27.00$ & & $<0.40 / 27.00$ \\
\hline \multicolumn{5}{|l|}{$\mathbf{P b}$} \\
\hline n (\%) & 100 & 100 & & 100 \\
\hline $\begin{array}{l}\text { Median (first/ } \\
\text { third quartile) }\end{array}$ & $\begin{array}{l}19.0 \\
(12.0 / 28.5)\end{array}$ & $\begin{array}{l}21 \\
(15.0 / 31.0)\end{array}$ & 0.26 & $\begin{array}{l}20.0 \\
(14.0 / 30.8)\end{array}$ \\
\hline $\begin{array}{l}\text { Minimum/ } \\
\text { maximum }\end{array}$ & $4.9 / 65.0$ & $6.6 / 240.0$ & & $4.9 / 240.0$ \\
\hline \multicolumn{5}{|l|}{$\mathrm{Hg}$} \\
\hline n (\%) & 81.1 & 84.7 & & 83.5 \\
\hline $\begin{array}{l}\text { Median (first/ } \\
\text { third quartile) }\end{array}$ & $\begin{array}{l}0.34 \\
(0.17 / 0.34)\end{array}$ & $\begin{array}{l}0.53 \\
(0.22 / 0.92)\end{array}$ & 0.02 & $\begin{array}{l}0.42 \\
(0.20 / 0.82)\end{array}$ \\
\hline $\begin{array}{l}\text { Minimum/ } \\
\text { maximum }\end{array}$ & $<0.13 / 2.10$ & $<0.13 / 11.00$ & & $<0.13 / 11.00$ \\
\hline
\end{tabular}

Notes: Heavy metal analysis in coronary artery disease patients including number of patients (\%) in whom each metal could be quantified. Data is presented as median (first to third quartile), minimum and maximum values, and $P$-value of sex-specific differences. For cadmium the first quartile is below the detection limit of $0.40 \mu \mathrm{g} / \mathrm{L}$. Abbreviations: $\mathrm{Cd}$, cadmium; $\mathrm{Hg}$, mercury; $\mathrm{Pb}$, lead.
$\mathrm{Pb}$, or $\mathrm{Hg}$. Performing multivariate analyses (with regard to the cardiovascular risk factors) did not show a significant correlation between the severity of CAD and the heavy metal levels. On the contrary, the coronary score correlated positively with laboratory markers that are associated with $\mathrm{CAD}$, eg, uric acid $(P=0.03)$, creatinine $(P=0.01)$, blood urea nitrogen (BUN) $(P=0.03)$, triglycerides $(P=0.03)$, $\mathrm{C}$-reative protein (CRP) $(P<0.01)$, pro brain natriuretic peptide (proBNP) $(P<0.01)$, and fibrinogen Clauss $(P<0.01)$, and negatively with high density lipoprotein (HDL) $(P=0.02)$. Furthermore, it correlated positively with BMI $(P=0.02)$.

Compared to mean $\mathrm{Cd}$ levels that were found in the German population $(0.335 \mu \mathrm{g} / \mathrm{L}$ urine $)$, the CAD patients showed much higher median levels $(0.67 \mu \mathrm{g} / \mathrm{L})$ and $34.1 \%$ of the CAD patients exceeded the HBM-I level of $1 \mu \mathrm{g} / \mathrm{L}$ and $8.5 \%$ of CAD patients exceeded the HBM-II level of $4 \mu \mathrm{g} / \mathrm{L}$. Concerning mean $\mathrm{Pb}$ and $\mathrm{Hg}$ levels in the German population (35.6 and $0.86 \mu \mathrm{g} / \mathrm{L}$ full blood, respectively), CAD patients showed much lower median levels (20 and $0.42 \mu \mathrm{g} / \mathrm{L}$, respectively) and HBM-I/II levels were exceeded only by single cases.

Concerning nutrition, significant positive correlations were found for $\mathrm{Pb}$ and the number of consumed units of red wine $(P=001)$ and white wine $(P<0.01)$ per week and for $\mathrm{Hg}$ with white wine $(P<0.01)$ and fish consumption $(P<0.01)$. Ex-smoking patients had significantly higher amounts of $\mathrm{Cd}$ in urine compared to patients who never smoked ( 0.84 versus $0.58 \mu \mathrm{g} / \mathrm{L}$, respectively; $P=0.03$ ). Also $\mathrm{Pb}$ was higher in full blood in ex-smokers compared to never-smokers but without statistical significance (21.5 versus $19.5 \mu \mathrm{g} / \mathrm{L}$, respectively; $P=0.15$ ). Patients with amalgam fillings showed significantly higher levels of $\mathrm{Hg}$ compared to patients without amalgam fillings ( 0.51 versus $0.27 \mu \mathrm{g} / \mathrm{L}$, respectively; $P<0.01$ ). Patients living in a big city ( $>100,000$ citizens) had median Cd levels of $0.62 \mu \mathrm{g} / \mathrm{L}, \mathrm{Pb}$ levels of $20.0 \mu \mathrm{g} / \mathrm{L}$, and $\mathrm{Hg}$ levels of $0.43 \mu \mathrm{g} / \mathrm{L}$. Patients living in a small town had median $\mathrm{Cd}$ 
levels of $0.82 \mu \mathrm{g} / \mathrm{L}, \mathrm{Pb}$ levels of $21.5 \mu \mathrm{g} / \mathrm{L}$, and $\mathrm{Hg}$ levels of $0.47 \mu \mathrm{g} / \mathrm{L}$, and patients who lived in rural areas had median $\mathrm{Cd}$ levels of $0.87 \mu \mathrm{g} / \mathrm{L}, \mathrm{Pb}$ levels of $22.5 \mu \mathrm{g} / \mathrm{L}$, and $\mathrm{Hg}$ levels of $0.33 \mu \mathrm{g} / \mathrm{L}$.

\section{Discussion}

Although heavy metal exposure by ubiquitous pollutants has frequently been associated with atherosclerosis, $\mathrm{Cd}, \mathrm{Hg}$, and $\mathrm{Pb}$ also play a tangential role in cardiovascular research and have been overshadowed by heavy weights such as hypertension, diabetes mellitus, and physical inactivity. This study is the first to correlate urine levels of $\mathrm{Cd}$ and blood levels of $\mathrm{Hg}$ and $\mathrm{Pb}$ with the extent of severity of CAD in $164 \mathrm{CAD}$ patients.

The main sources of contamination (dependent on the metal) are industry, traffic, tobacco consumption, and agriculture/nutrition. Heavy metals are long lasting substances which persist for decades, are transported within environmental media, and are partly accumulated in individuals after incorporation. ${ }^{29}$ Within $\mathrm{CAD}$ patients, $\mathrm{Pb}$ levels and the number of consumed units of red and white wine per week, and $\mathrm{Hg}$ levels and white wine and fish consumption correlated positively. Concerning red wine consumption and $\mathrm{Pb}$, this correlation has been shown before, ${ }^{30-32}$ even within the female Austrian population. ${ }^{33}$ However, a connection between blood $\mathrm{Hg}$ levels and white wine consumption is hard to find in literature. On the contrary, much research has been done investigating the influence of fish consumption and $\mathrm{Hg}$ levels, especially methyl-mercury. The correlation between $\mathrm{Hg}$ amounts in blood and fish consumption has been described in large studies (eg, in the Canadian population ${ }^{34}$ and US children and women ${ }^{35}$ ). However, although $\mathrm{Hg}$ intake by fish consumption seems unequivocal the cardioprotective effects of a fish-rich diet seem to predominate. The Diet and Reinfarction Trial ${ }^{36}$ studied the influence of fish oil intake on total mortality and myocardial infarction (MI) in more than 2,000 men who had already suffered an MI with a follow-up period of 2 years. Patients who were asked to consume fish 2 times/week showed a $29 \%$ reduction in total mortality which was mostly driven by a $32 \%$ reduction in fatal MI. Other studies showed similar results ${ }^{18,37-39}$ and considering these results it seems that the positive effect of fish consumption on the cardiovascular system predominates but might be diminished by $\mathrm{Hg}$ content.

A further source of pollution, this time for $\mathrm{Cd}$, seems to be nicotine consumption and second hand smoking, as shown in several studies, ${ }^{40-42}$ and this was also observed in our CAD patients. Although we recruited only patients who never smoked or stopped smoking at least 7 years ago, ex-smokers had about $76 \%$ higher levels, probably due to bioaccumulation of $\mathrm{Cd}$. Furthermore, we found significantly higher levels of $\mathrm{Hg}$ in patients with amalgam fillings compared to patients without amalgam fillings, although this topic cannot escape controversy. However, concerning the place of residence (urban, suburban, rural) we found no connection to $\mathrm{Cd}, \mathrm{Hg}$, or $\mathrm{Pb}$.

As mentioned before, the core of this study was the investigation of heavy metal levels in blood and urine in patients with CAD of different, but exactly quantified severity, by means of angiography. Firstly, it has to be said that the CAD patients showed much higher median urinary $\mathrm{Cd}$ levels compared to levels that were found in the German population. ${ }^{25}$ Furthermore, it was striking that although $\mathrm{Cd}$ was only quantifiable in $68.3 \%$ of patients, nearly $34.1 \%$ of all patients exceeded the HBM-I level of $1 \mu \mathrm{g} / \mathrm{L}$ in urine. Within the European HBM study Demo-COPHES (consortium to perform human biomonitoring on a European scale), mean levels in women (age $<45$ years) were $0.22 \mu \mathrm{g} / \mathrm{L}$ and the $90 \%$ percentile was 0.62. ${ }^{43}$ Concerning $\mathrm{Pb}$ and $\mathrm{Hg}$, we found levels which were much lower in nearly all patients compared to both the German population ${ }^{25}$ and reference levels, ${ }^{26}$ respectively. Messner et $\mathrm{al}^{10}$ found a significant association of $\mathrm{Cd}$ levels in serum and intima media thickness in young healthy female individuals as a sign for early atherosclerosis. ${ }^{44}$ We analyzed urinary $\mathrm{Cd}$ and blood $\mathrm{Hg}$ and $\mathrm{Pb}$ amounts and quantified the severity of CAD but found no correlations. To this extent, this appears as rather surprising as the system of CAD quantification (described in the Materials and Methods section) seems to be appropriate because the score correlated positively with several (established) parameters of atherosclerosis (uric acid, creatinine, triglycerides, BUN, CRP, BMI, proBNP) and negatively with HDL cholesterol, even when these patients were under medication. One point of criticism may be that patients with long-term $\mathrm{CAD}$ and previous stent implants were also recruited. However, within the study group 50.6\% had never had a cardiovascular event and there was again no observable correlation between heavy metals and severity of CAD. Unfortunately, although literature delivers interesting findings, the comparison of data is often difficult because heavy metal amounts are measured in various media (full blood, urine, hair, toenails, liver/kidney tissue). It is well recognized that once individuals are exposed to $\mathrm{Cd}, \mathrm{Pb}$, or $\mathrm{Hg}$ the metals can be detected in blood and urine but are quickly sequestered into tissue. ${ }^{45}$ It is therefore difficult to reveal the total burden of $\mathrm{Cd}$, $\mathrm{Hg}$, and $\mathrm{Pb}$ on the body. However, as the vascular system was in the foreground of this study the measurement of $\mathrm{Hg}$ and $\mathrm{Pb}$ in blood and $\mathrm{Cd}$ in urine was obvious despite the fact that several circumstances ${ }^{46}$ may affect the levels in these media. 
Furthermore, analysis is partly made in animals or humans which/who were confronted with enormous and (for "normal" populations) unrealistic heavy metal exposure, eg, rabbits which were fed with $8 \mathrm{mg} \mathrm{Cd} / \mathrm{kg} /$ day over 8 months ${ }^{47}$ or $\mathrm{Hg}$ determination in workers of a chlorine producing factory. ${ }^{48}$

The present study is the first that assesses $\mathrm{Cd}, \mathrm{Pb}$, and $\mathrm{Hg}$ levels in CAD patients with precisely quantified CAD. Considering the results of this study, it seems very probable that nutrition (above all, fish and alcohol consumption) and smoking are the main sources of heavy metal incorporation but it seems unlikely that $\mathrm{Cd}, \mathrm{Hg}$, or $\mathrm{Pb}$, in quite low amounts, play a major role in the genesis of CAD, particularly when compared to the influence of blood pressure, blood glucose, and lipid profile in Austria.

\section{Limitations}

Circulating heavy metal levels are influenced by numerous circumstances making it hard to control. Due to the dynamics of heavy metal pollutants, a single blood/urine sample does not reflect the total body burden but as the vasculature damage was in the foreground of this study it seemed the most appropriate.

\section{Funding sources}

This study was funded by means of the Medical University of Vienna and the Environment Agency Austria.

\section{Acknowledgments}

The authors give special thanks to the laboratory team of the Medical University of Vienna.

\section{Disclosure}

The authors have no disclosure to make.

\section{References}

1. European Cardiovascular Disease Statistics 2012 [webpage on the Internet]. Brussels: European Heart Network; 2012. Available from: http://www.ehnheart.org/cvd-statistics.html. Accessed April 6, 2014.

2. Kalin MF, Zumoff B. Sex hormones and coronary disease: a review of the clinical studies. Steroids. 1990;55(8):330-352.

3. Isles CG, Hole DJ, Hawthorne VM, Lever AF. Relation between coronary risk and coronary mortality in women of the Renfrew and Paisley survey: comparison with men. Lancet. 1992;339(8795):702-706.

4. Wingard DL, Barrett-Connor EL, Scheidt-Nave C, McPhillips JB. Prevalence of cardiovascular and renal complications in older adults with normal or impaired glucose tolerance or NIDDM. A population-based study. Diabetes Care. 1993;16(7):1022-1025.

5. Fifth Joint Task Force of the European Society of Cardiology; European Association of Echocardiography; et al. European Guidelines on cardiovascular disease prevention in clinical practice (version 2012): The Fifth Joint Task Force of the European Society of Cardiology and Other Societies on Cardiovascular Disease Prevention in Clinical Practice (constituted by representatives of nine societies and by invited experts). Eur J Prev Cardiol. 2012;19(4):585-667.
6. Alsberg CL, Schwartze EW. Pharmacological action of Cd. Pharmacology. 1919;13:504-509.

7. Bhatnagar A. Environmental cardiology: studying mechanistic links between pollution and heart disease. Circ Res. 2006;99(7):692-705.

8. Navas-Acien A, Silbergeld EK, Sharrett R, Calderon-Aranda E, Selvin E, Guallar E. Metals in urine and peripheral arterial disease. Environ Health Perspect. 2005;113(2):164-169.

9. Tellez-Plaza M, Navas-Acien A, Crainiceanu CM, Guallar E. Cadmium exposure and hypertension in the 1999-2004 National Health and Nutrition Examination Survey (NHANES). Environ Health Perspect. 2008;116(1):51-56.

10. Messner B, Knoflach M, Seubert A, et al. Cadmium is a novel and independent risk factor for early atherosclerosis mechanisms and in vivo relevance. Arterioscler Thromb Vasc Biol. 2009;29(9):1392-1398.

11. Prozialeck WC. Evidence that E-cadherin may be a target for cadmium toxicity in epithelial cells. Toxicol Appl Pharmacol. 2000;164(3): 231-249.

12. Seok SM, Park DH, Kim YC, et al. COX-2 is associated with cadmiuminduced ICAM-1 expression in cerebrovascular endothelial cells. Toxicol Lett. 2006;165(3):212-220.

13. Galan A, Garcia-Bermejo L, Troyano A, et al. The role of intracellular oxidation in death induction (apoptosis and necrosis) in human promonocytic cells treated with stress inducers (cadmium, heat, X-rays). Eur J Cell Biol. 2001;80(4):312-320.

14. Choi AL, Weihe P, Budtz-Jorgensen E, et al. Methylmercury exposure and adverse cardiovascular effects in Faroese whaling men. Environ Health Perspect. 2009;117(3):367-372.

15. Valera B, Dewailly E, Poirier P. Cardiac autonomic activity and blood pressure among Nunavik Inuit adults exposed to environmental mercury: a cross-sectional study. Environ Health. 2008;7:29.

16. Fillion M, Mergler D, Sousa Passos CJ, Larribe F, Lemire M, Guimaraes JR. A preliminary study of mercury exposure and blood pressure in the Brazilian Amazon. Environ Health. 2006;5:29.

17. Wojciechowski J, Kowalski W. Cardiac and aortic lesions in chronic experimental poisoning with mercury vapors. Pol Med Sci Hist Bull. 1975;15(2):255-260.

18. Guallar E, Sanz-Gallardo MI, van't Veer P, et al. Mercury, fish oils, and the risk of myocardial infarction. $N$ Engl J Med. 2002;347(22): $1747-1754$.

19. Salonen JT, Seppanen K, Lakka TA, Salonen R, Kaplan GA. Mercury accumulation and accelerated progression of carotid atherosclerosis: a population-based prospective 4-year follow-up study in men in eastern Finland. Atherosclerosis. 2000;148(2):265-273.

20. Alghasham AA, Meki AR, Ismail HA. Association of blood lead level with elevated blood pressure in hypertensive patients. Int J Health Sci (Qassim). 2011;5(1):17-27.

21. Hu H, Aro A, Payton M, et al. The relationship of bone and blood lead to hypertension. The Normative Aging Study. JAMA. 1996;275(15): 1171-1176.

22. Tsao DA, Yu HS, Cheng JT, Ho CK, Chang HR. The change of betaadrenergic system in lead-induced hypertension. Toxicol Appl Pharmacol. 2000;164(2):127-133.

23. Khalil-Manesh F, Gonick HC, Weiler EW, Prins B, Weber MA, Purdy RE. Lead-induced hypertension: possible role of endothelial factors. Am J Hypertens. 1993;6(9):723-729.

24. Farmand F, Ehdaie A, Roberts CK, Sindhu RK. Lead-induced dysregulation of superoxide dismutases, catalase, glutathione peroxidase, and guanylate cyclase. Environ Res. 2005;98(1):33-39.

25. Umwelt-Survey. Umwelt-Survey/Bd.7: 1998. Arsen, Schwer-und Edelmetalle in Blut und Urin der Bevölkerung in Deutschland [Arsenic, heavy and precious metals in blood and urine of the population in Germany]. Available from: http://www.umweltbundesamt. de/publikationen/umwelt-survey-1998-4. Accessed April 28, 2014. German. 
26. Bundesgesundheitsbl-Gesundheitsforsch-Gesundheitsschutz. Aktualisierung der Referenzwerte für Blei, Cadmium und Quecksilber im Blut und Urin von Erwachsenen - Stellungnahme der Kommission "Human-Biomonitoring" des Umweltbundesamtes [Update on the reference values for lead, cadmium and mercury in the blood and urine of adults - Commission Opinion on "Human Biomonitoring" of the Federal Environment Agency]. 2003. Available from: http:// www.umweltbundesamt.at/fileadmin/site/umweltthemen/gesundheit/ Humanbiomonitoring.pdf. Accessed April 28, 2014. German.

27. Schulz C, Wilhelm M, Heudorf U, Kolossa-Gehring M; Human Biomonitoring Commission of the German Federal Environment Agency. Update of the reference and HBM values derived by the German Human Biomonitoring Commission. Int J Hyg Environ Health. 2011;215(1):26-35.

28. Wilhelm M, Heinzow B, Angerer J, Schulz C. Reassessment of critical lead effects by the German Human Biomonitoring Commission results in suspension of the human biomonitoring values (HBM I and HBM II) for lead in blood of children and adults. Int J Hyg Environ Health. 2010;213(4):265-269.

29. Bressler JP, Olivi L, Cheong JH, Kim Y, Bannona D. Divalent metal transporter 1 in lead and cadmium transport. Ann NY Acad Sci. 2004;1012:142-152.

30. Tahvonen R. Lead and cadmium in beverages consumed in Finland. Food Addit Contam. 1998;15(4):446-450.

31. Cvetkovic J, Arpadjan S, Karadjova I, Stafilov T. Determination of cadmium in wine by electrothermal atomic absorption spectrometry. Acta Pharm. 2006;56(1):69-77.

32. Tariba B. Metals in wine - impact on wine quality and health outcomes. Biol Trace Elem Res. 2011;144(1-3):143-156.

33. Gundacker C, Komarnicki G, Zodl B, Forster C, Schuster E, Wittmann K. Whole blood mercury and selenium concentrations in a selected Austrian population: does gender matter? Sci Total Environ. 2006;372(1):76-86.

34. Lye E, Legrand M, Clarke J, Probert A. Blood total mercury concentrations in the Canadian population: Canadian Health Measures Survey cycle 1, 2007-2009. Can J Public Health. 2013;104(3):e246-e251.

35. Schober SE, Sinks TH, Jones RL, et al. Blood mercury levels in US children and women of childbearing age, 1999-2000. JAMA. 2003;289(13):1667-1674.

36. Burr ML, Fehily AM, Gilbert JF, et al. Effects of changes in fat, fish, and fibre intakes on death and myocardial reinfarction: diet and reinfarction trial (DART). Lancet. 1989;2(8666):757-761.
37. Rissanen T, Voutilainen S, Nyyssonen K, Lakka TA, Salonen JT. Fish oil-derived fatty acids, docosahexaenoic acid and docosapentaenoic acid, and the risk of acute coronary events: the Kuopio ischaemic heart disease risk factor study. Circulation. 2000;102(22):2677-2679.

38. Chan HM, Egeland GM. Fish consumption, mercury exposure, and heart diseases. Nutr Rev. 2004;62(2):68-72.

39. Stern AH. A review of the studies of the cardiovascular health effects of methylmercury with consideration of their suitability for risk assessment. Environ Res. 2005;98(1):133-142.

40. Tellez-Plaza M, Navas-Acien A, Caldwell KL, Menke A, Muntner P, Guallar E. Reduction in cadmium exposure in the United States population, 1988-2008: the contribution of declining smoking rates. Environ Health Perspect. 2012;120(2):204-209.

41. Leung TF, Chan IH, Liu TC, Lam CW, Wong GW. Relationship between passive smoking exposure and urinary heavy metals and lung functions in preschool children. Pediatr Pulmonol. 2013;48(11):1089-1097.

42. McElroy JA, Shafer MM, Trentham-Dietz A, Hampton JM, Newcomb PA. Urinary cadmium levels and tobacco smoke exposure in women age 20-69 years in the United States. JToxicol Environ Health A. 2007;70(20):1779-1782.

43. COPHES: consortium to perform human biomonitoring on a European scale (COPHES). Cent Eur J Public Health. 2012;20(4):300.

44. Magyar MT, Szikszai Z, Balla J, et al. Early-onset carotid atherosclerosis is associated with increased intima-media thickness and elevated serum levels of inflammatory markers. Stroke. 2003;34(1):58-63.

45. Archibeque-Engle SL, Tessari JD, Winn DT, Keefe TJ, Nett TM, Zheng T. Comparison of organochlorine pesticide and polychlorinated biphenyl residues in human breast adipose tissue and serum. J Toxicol Environ Health. 1997;52(4):285-293.

46. Jandacek RJ, Anderson N, Liu M, Zheng S, Yang Q, Tso P. Effects of yo-yo diet, caloric restriction, and olestra on tissue distribution of hexachlorobenzene. Am J Physiol Gastrointest Liver Physiol. 2005;288(2):G292-G299.

47. Subramanyam G, Bhaskar M, Govindappa S. The role of cadmium in induction of atherosclerosis in rabbits. Indian Heart J. 1992;44(3): 177-180.

48. Skoczynska A, Jedrejko M, Martynowicz H, et al. [The cardiovascular risk in chemical factory workers exposed to mercury vapor]. Med Pr. 2010;61(4):381-391. Polish.
Vascular Health and Risk Management

\section{Publish your work in this journal}

Vascular Health and Risk Management is an international, peerreviewed journal of therapeutics and risk management, focusing on concise rapid reporting of clinical studies on the processes involved in the maintenance of vascular health; the monitoring, prevention and treatment of vascular disease and its sequelae; and the involvement of

\section{Dovepress}

metabolic disorders, particularly diabetes. This journal is indexed on PubMed Central and MedLine. The manuscript management system is completely online and includes a very quick and fair peer-review system, which is all easy to use. Visit http://www.dovepress.com/ testimonials.php to read real quotes from published authors. 